\title{
Analisa Teknis Ekonomis Penggunaan Kulit Plastik HDPE Sebagai Pengganti Kulit Kayu Pada Lambung Perahu Katamaran
}

\author{
Wilma Amiruddin ${ }^{\left.l)^{*}\right)}$ \\ ${ }^{1)}$ Departemen Teknik Perkapalan, Fakultas Teknik, Universitas Diponegoro \\ Jl. Prof. Soedarto, SH, Kampus Undip Tembalang, Semarang, Indonesia 50275
}

diajukan pada :11/03/19 direvisi pada $: 13 / 05 / 19 \quad$ diterima pada $: 29 / 05 / 19$

\begin{abstract}
Abstrak
Pembuatan perahu katamaran berkulit plastik HDPE akan memberikan pengaruh secara teknis maupun ekonomis. Faktor berat dan desain akan berkorelasi secara langsung terhadap hambatan perahu dan perubahan kapasitas muatnya. Tujuan dari penelitian ini adalah melihat manfaat yang diperoleh dari penggunaan bahan alternatif yang dimaksud. Penelitian dilakukan dengan cara melakukan observasi, melakukan analisis berdasarkan rumus empiris, dan melakukan penilaian teknis berdasarkan kriteria yang ditetapkan dalam perencanaan kapal katamaran. Hasil analisa menunjukkan terjadi pengurangan berat sebesar $256 \mathrm{~kg}( \pm 25 \%)$, di mana LWT perahu HDPE lebih ringan dari pada perahu berkulit kayu. Pengurangan berat tersebut memberikan pengaruh terhadap efesiensi kapasitas muat $\pm 50 \%$. Perahu berkulit plastik HDPE menghasilkan hambatan total (RT) sebesar $510 \mathrm{~N}$ dan perahu katamaran kayu sebesar 560 N. Hasil pengecekan kriteria desain perahu katamaran menunjukkan hampir semua kriteria terpenuhi, baik untuk perahu kayu maupun perahu berkulit plastik HDPE., kecuali nilai block coefficient (Cb) yang relatif cukup besar, yaitu $C b=0,7$.
\end{abstract}

Copyright (C) 2019, KAPAL, 1829-8370 (p), 2301-9069(e)

Kata Kunci : Katamaran, Plastik HDPE, Kayu

\section{PENDAHULAN}

Sebuah pertanyaan yang mengemuka ketika dikakukan sebuah rekayasa atau modifikasi kapal atau perahu adalah seberapa manfaat yang akan diperoleh dari hasil rekayasa tersebut. Pembuatan perahu katamaran berkulit plastik HDPE dari bekas drum kemasan akan memberikan pengaruh utama pada berat displasemen perahu. Perbedaan berat tersebut akan memberikan konskwensi terhadap besarnya nilai hambatan perahu dan akan berkorelasi terhadap biaya operasional, dalam hal ini penggunaan bahan bakar, di lain pihak perbedaan berat juga akan menentukan besarnya kapasitas muatan yang akan diangkut.

Pembuatan perahu katamaran berkulit plastik HDPE merupakan salah satu solusi inovatif untuk

\footnotetext{
*) Penulis Korespondensi :

Email : wilmaamiruddin@yahoo.com
}

meningkatkan produktivitas pengrajin perahu tradisional. Sebuah perahu katamaran berkulit plastik HDPE telah dibangun dengan ukuran utama panjang seluruh, Loa $=6,6 \mathrm{~m}$, lebar seluruh Boa $=3 \mathrm{~m}$, dan tinggi geladak, $\mathrm{D}=0,5 \mathrm{~m}$. $\mathrm{Cb}$ $=0,7, \mathrm{Cwl}=0,8$, tebal kulit $= \pm 8 \mathrm{~mm}$, dan berat jenis material $\rho=0,97\left(\right.$ ton $\left./ \mathrm{m}^{3}\right)$. Mesin penggerak luar yang digunakan adalah mesin luar (tempel) dengan daya 6,5 PK. Pembuatan perahu tersebut diharapkan dapat memberikan keuntungan teknis maupun ekonomis.

Beberapa hal yang bersifat khusus tentang pembuatan perahu secara tradisional, antara lain metode pembuatan yang diperoleh secara turun temurun dari generasi sebelumnya. Sudah barang tentu dalam kasus ini ada beberapa kriteria teknis yang tidak memdapatkan perhatian sebagaimana kriteria yang telah ditetapkan berdasarkan standart perancangan kapal, misalnya ketentuan tentang 
jarak antar lambung $k=b / L$. Pengrajin perahu lebih menekankan pada aspek ekonomis, dengan cara membuat area geladak yang relatif luas. Nilai rasio $\mathrm{k}$ tersebut secara langsung akan berpengaruh terhadap bentuk dan luas geladak.

Berdasarkan uraian di atas, perlu dilakukan pengeceken terhadap beberapa kriteria teknis perencanaan kapal katamaran yang belum diketahui, antara lain nilai rasio $\mathrm{k}$. Rasio nila $\mathrm{k}$ yang baik, yaitu nilai $\mathrm{k}$ yang dapat meminimalkan tahanan gelombang yaitu nilai $\mathrm{k}= \pm 0,3$ dengan bilangan Froude Number sekitar 0,33 [1]. Gambar 1. menunjukkan kapal katamaran berkulit plastik HDPE yang digunakan sebagai materi penelitian.

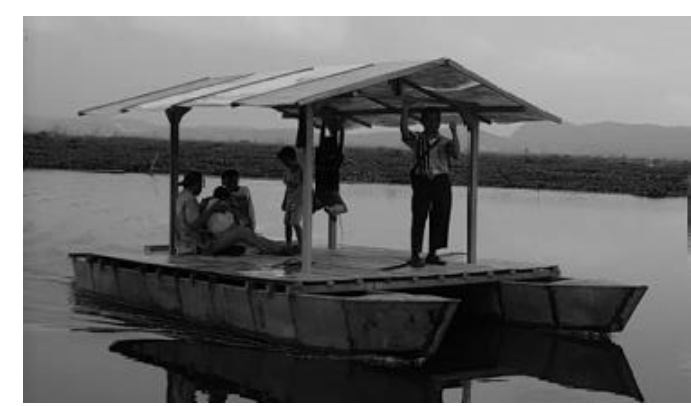

Gambar 1. Katamaran Berkulit Plastik HDPE.

Pertimbangan dalam memilih plastik HDPE bekas drum kemasan sebagai bahan alrenatif pengganti kulit kayu adalah bahan tersebut memiliki stock melimpah, murah, mudah dalam pengerjaan dan memilki karakteristik teknis yang mendukung sebagai bahan alternatif yang dimaksud. Karakteristik teknis yang cukup baik dari jenis plastik HDPE adalah temperatur leleh berkisar antara $200-280^{\circ} \mathrm{C}$ [2], dan kekuatan tarik 1200-2000 Psi [3]. Penggunaan plastik HDPE bekas drum kemasan pada perahu monohull menjadikan berat lambung berkurang \pm $30 \%$ dari berat lambung perahu berkulit kayu [4].

Berdasarkan aspek desain, secara umum diketahui bahwa perahu katamaran memberikan keunggulan pada aspek stabilitas yang lebih baik dan luas geladak yang lebih besar. Oleh sebab itu, fokus penelitian ini lebih diarahkan pada pengaruh berat dari penggunaan plastik HDPE sebagai kulit lambung, terutama jika dibandingkan dengan penggunaan material kayu.

Perubahan luas permukaan basah (WSA) kapal karena perubahan displasemen berat kapal akan menimbulkan perubahan terhadap nilai hambatan kapal. Perubahan nilai hambatan yang cukup besar akan berimplikasi terhadap biaya operasional yang besar pula, hal mana berlaku sebaliknya. Perubahan displasemen yang cukup signifikan juga akan menyebabkan terjadinya pergeseran titik berat kapal. Nilai radius metasenter di atas titik berat kapal (GM) akan bergeser kedudukannya secara vertikal manakala terjadi perubahan berat dari total berat displasemen perahunya. Pergeseran titik berat ini menyebabkan perubahan karakter stabilitas kapal. Nilai radius metasenter yang kecil mencirikan karakter stabilitas yang kurang baik, hal mana berlaku sebaliknya.

Perbedaan berat yang timbul karena perbedaan dalam penggunaan jenis material, maka pada ukuran displasemen yang sama menyebabkan perbedaan kapasitas muatnya. Dalam hal ini penggunaan material yang lebih ringan akan memberikan keuntungan ekonomis, karena perahu akan memiliki kapasitas muat yang lebih besar.

Selain perhatian terhadap perubahan berat akibat perubahan jenis material yang dimaksud, perhatian lain yang penting dilakukan adalah pemeriksaan terhadap faktor-faktor yang berkaitan dengan desain perahu katamaran. Faktor-faktor desain tersebut antara lain nilai perbandingan jarak center line dari demihull terhadap panjang garis air kapal (s/Lwl), perbandingan antara nilai Lwl dengan lebar demihull (Lwl/B1), dll. Ukuranukuran tersebut diperoleh dari hasil observasi di lapangan (tempat pembuatan perahu). Berdasarkan hasil observasi tersebut dilakukan analisa dan penilaian dengan menggunakan kriteria-kriteria desain untuk kapal katamaran. Tujuan dari kajian ini adalah untuk melihat pengaruh penggunaan plastik HDPE pada perahu katamaran, baik secara teknis maupun ekonomis sehingga dapat digunakan sebagai bahan pertimbangan dalam meningkatkan produktifitas industri perahu.

\section{METODE}

\subsection{Hambatan Kapal}

Besarnya nilai hambatan dari sebuah perahu atau kapal bersifat proporsional terhadap besarnya nilai displasemen kapalnya. Hal ini berarti setiap perubahan yang terkait dengan berat displasemen akan berpengaruh linear terhadap nilai hambatan kapalnya.

Perubahan displasemen pada rasio $\mathrm{B} / \mathrm{T}$ yang sama akan menghasilkan hambatan yang nilainya proporsional. Hambatan gesek memiliki nilai pada kisaran $60-70 \%$, sedang nilai hambatan sisa 30 $40 \%$. Jika displasemen pada kapal monohull dibagi menjadi dua dengan nilai total displasemen sama, demikian juga dengan nilai rasio $\mathrm{B} / \mathrm{T}$ yang sama, maka masing-masing lambung dari kapal katamaran akan mendapatkan nilai hambatan gesek $60-70 \%$ dengan hambatan sisa $30-40 \%$. Jumlah total hambatan dari lambung kapal 
katamaran menjadi $\pm 140 \%$ untuk hambatan gesek, dan $\pm 60 \%$ untuk hambatan sisa [1]

Hasil penelitian lain yang memperbandingkan model kapal katamaran dengan S/L 0,4 - S/L 0,5, terhadap model kapal monohull. Perbedaan bentuk model dilakukan dengan mempertahankan kesamaan pada nilai displasemen dan daya mesinnya. Diperoleh hasil bahwa hambatan kapal katamaran lebih kecil dari kapal monohull. [5]

Nilai hambatan dapat diperoleh melalui persamaan yang dibentuk berdasarkan atas karakteristik fisik fluida, densitas $\rho$, viskositas $\mu$, V kecepatan fliuda, dan L panjang objek, sebagai berikut [6] : $R=f\left[L^{\mathrm{a}} V^{\mathrm{b}} \rho^{\mathrm{c}} \mu^{\mathrm{d}} g^{\mathrm{e}} p^{\mathrm{f}}\right]$. Persamaan di atas dapat diekspresikan kedalam bentuk satuan ukuran dasar, sebagai berikut :

$$
\frac{M L}{T^{2}}=f\left[L^{a}\left(\frac{L}{T}\right)^{b}\left(\frac{M}{L^{3}}\right)^{c}\left(\frac{M}{L T}\right)^{d}\left(\frac{L}{T^{2}}\right)^{e}\left(\frac{M}{L T^{2}}\right)^{f}\right]
$$

Persamaan di atas dapat disederhanakan :

$$
R=\rho V^{2} L^{2} f\left[\left(\frac{\mu}{\rho V L}\right)^{\mathrm{d}},\left(\frac{g L}{V^{2}}\right)^{\mathrm{e}},\left(\frac{p}{\rho V^{2}}\right)^{\mathrm{f}}\right]
$$

Selanjutnya persamaan untuk hambatan dapat dituliskan :

$$
\begin{gathered}
R=\rho V^{2} L^{2}\left[f_{1}\left(\frac{\mu}{\rho V L}\right), f_{2}\left(\frac{g L}{V^{2}}\right), f_{3}\left(\frac{p}{\rho V^{2}}\right)\right] \\
\frac{R}{\rho V^{2} L^{2}}, V L \frac{\rho}{\mu}, \frac{V}{(g L)^{0.5}}, \frac{\mathrm{p}}{\rho V^{2}} \\
R=\rho V^{2} L^{2}\left[f_{1}\left(\frac{v}{V L}\right)+f_{2}\left(\frac{g L}{V f t 1^{2}}\right)\right]
\end{gathered}
$$

Terkait dengan nilai $\mathrm{f}_{2}$ tdua kapal dengan geometri yang sama, persamaan hambatan gelombangnya dapat dituliskan, sebagai berikut :

$$
R_{w 1}=\rho_{1} V_{1}^{2} L_{1}^{2} f_{2}\left(\frac{g L_{1}}{V_{1}^{2}}\right)
$$

dan

$$
R_{w 2}=\rho_{2} V_{2}^{2} L_{2}^{2} f_{2}\left(\frac{g L_{2}}{V_{2}^{2}}\right)
$$

Maka :

$$
\frac{\rho_{2}}{\rho_{1}} \times \frac{V_{2}^{2}}{V_{1}^{2}} \times \frac{L_{2}^{2}}{L_{1}^{2}} \times \frac{f_{2}\left(g L_{2} / V_{2}^{2}\right)}{f_{2}\left(g L_{1} / V_{1}^{2}\right)}
$$

Untuk nilai $f_{2}$ yang tidak diketahui, tetapi diberikan nilai $g L_{1} / V_{1}^{2}=g L_{2} / V_{2}^{2}$, sehingga nilai $f_{2}$ menjadi sama, maka :

$$
\frac{R_{w 2}}{R_{w 1}}=\frac{\rho_{2} V_{2}^{2} L_{2}^{2}}{\rho_{1} V_{1}^{2} L_{1}^{2}}
$$

Sementara, $L_{1} / V_{1}^{2}=L_{2} / V_{2}^{2}$, maka :

$$
\frac{R_{w 2}}{R_{w 1}}=\frac{\rho_{2} L_{2}^{3}}{\rho_{1} L_{1}^{3}}, \text { atau } \frac{R_{w 2}}{R_{w 1}}=\frac{\Delta_{2}^{3}}{\Delta_{1}^{3}}
$$

Berdasarkan penjabaran persamaan di atas dapat diketahui sebuah hubungan tahanan gelombang terhadap displasemennya. Pada umumnya nilai hambatan (R) di atas dinyatakan dalam satuan $\mathrm{kg} . \mathrm{m} / \mathrm{dt}^{2}$, sedangkan displasemen $(\Delta)$ dalam $\mathrm{kg}$ atau Ton.

Hasil pengujian test model katamaran, penurunan nilai rasio panjang kapal (L) terhadap desplasemennya $(\mathrm{V}), \mathrm{L} / \mathrm{V}^{1 / 3}$, akan memberikan pengaruh terhadap peningkatan nilai hambatannya. Sedangkan nilai rasio jarak centerline lambung terhadap panjang kapalnya, $\mathrm{S} / \mathrm{L}$, terdapat perbedaan sedikit ketika terjadi kenaikan pada kecepatan kapalnya [7].

Selain hambatan sisa, penyusun nilai hambatan total lain dan merupakan jumlah komposisi terbesar dari hambatan total kapal adalah hambatan gesek, dapat dihitung dengan menggunakan koefisien hambatan gesek, melalui pendekatan rumus ITTC :

$$
C_{f}=\frac{R_{f}}{0,5 \cdot \rho S V^{2}}=\frac{0,075}{\left(\log _{10} R_{n}-2\right)^{2}}
$$

dimana $: \mathrm{Rn}=$ Bilangan Reynold

Terdapat beberapa rumus empiris untuk menentukan luas permukaan basah, antara lain perhitungan dengan memperhatikan nilai fungsi sarat $\mathrm{T}$, rumus empiris yang dimaksud dapat dilihat pada Persamaan 12 [6].

$$
S=L(C b \cdot B+1,7 T)
$$

$\mathrm{S}=$ luas permukaan basah, $\mathrm{Cb}=$ koefisien balok, $\mathrm{L}=$ panjang kapal, $\mathrm{T}=$ sarat kapal.

Telah diketahui dengan jelas bahwa hambatan gesek suatu kapal akan dipengaruhi oleh luas permukaan basahnya. Seluruh kapal katamaran akan memiliki luas permukaaan basah yang lebih besar dari pada kapal monohull untuk displasemen yang sama, sehingga hal ini mengakibatkan besar tahanan gesek yang lebih besar untuk kapal katamaran. Perbedaan luas permukaan basah dari kedua jenis kapal tersebut dapat ditunjukkan dengan perbandingan nilai luas permukaan basah dengan displasemennya $S / \sqrt{\Delta L}$. Tabel 1 . 
menunjukkan perbandingan luas permukaan basah yang dimaksud.

Tabel 1. Perbandingan luas permukaan basah [8]

\begin{tabular}{lc}
\hline \multicolumn{1}{c}{ Ship Type } & $\mathrm{S} / \sqrt{\Delta \boldsymbol{L}} /\left(\frac{\mathbf{S}}{\sqrt{\Delta L}}\right)$ monohull \\
\hline Monohull & 1 \\
Conventional & 1,4 \\
Catamaran & \\
Low waterplane & 2,3 \\
Catamaran & \\
Semisubmerged & 2,3 \\
Catamaran & \\
\hline
\end{tabular}

\subsection{Karakteristik Desain Katamaran}

Terdapat beberapa karakteristik desain sebagai kriteria untuk mendapatkan performa kapal katamaran yang baik. Karakteristik desain dalam kajian ini mengacu pada kriteria, sebagai berikut :

Tabel 2. Kriteria Desain Katamaran [9]

\begin{tabular}{ccc}
\hline \multirow{2}{*}{ Kriteria } & \multicolumn{2}{c}{ Standar } \\
& Minimum & Maksimum \\
\hline L/B1 & 6 & 12 \\
B/H & 0,7 & 4,1 \\
s/L & 0,19 & 0,51 \\
S/B1 & 0,9 & 4,1 \\
B1/T & 0,9 & 3,1 \\
Cb & 0,36 & 0,59 \\
\hline
\end{tabular}

Pertimbangan kriteria yang lain untuk nilai s/L atau $\mathrm{k}$, dapat digunakan, sebagai berikut [1] : untuk nilai $\mathrm{k}=0,33-0,45$ dan hampir semua nilai $\mathrm{k}$ mendapat nilai hambatan gelombang minimum pada bilangan $\mathrm{Fn}=0,33-0,34$.

\subsection{Pengambilan dan Pengolahan Data}

Observasi lapangan (di tempat pembuatan perahu) dilakukan untuk mendapatkan data-data perahu katamaran berkulit plastik HDPE yang sementara dibangun hingga proses peluncuran. Data-data hasil observasi akan di analisa dengan menggunakan kriteria yang berlaku dalam Teori Bangunan Kapal dan beberapa krteria khusus terkait dengan desain katamaran. Beberapa ketentuan untuk kriteria kapal monohull juga berlaku untuk kriteria demihull pada katamaran [1]. Oleh sebab itu analisa karakteristik teknis perahu katamaran juga akan mengacu pada sebagian kriteria-kriteria yang ditetapkan untuk desain kapal monohull.
Faktor tahanan perahu katamaran yang timbul dan bersifat dominan adalah tahanan gesek yang dapat mencapai $70 \%$ dari tahanan total kapal [1] . Jika ukuran utama, faktor bentuk dan sistem serta daya mesin sama (mesin tempel 6,5 pk), maka dapat diasumsikan nilai tahanan sisa dari perahu katamaran diperbandingkan akan memiliki nilai yang sama pula atau berbeda tidak signifikan, sehingga fokus perhitungan hanya pada faktor hambatan gesek. Mengacu pada perkiraan prosentase nilai hambatan di atas maka nilai hambatan total hasil perhitungan dari kapal yang berbeda bahan kulit lambung tersebut dapat dihitung. Perhitungan hambatan total tersebut akan dibutuhkan untuk menghitung kebutuhan daya dari kapal.

Berdasarkan uraian di atas dapat dijelaskan tahapan perhitungan melalui rumusan sebagai berikut :

$$
\mathrm{Rf}=0,5 . \text { Cf.p.S. } \mathrm{V}^{2}
$$

$$
\begin{aligned}
C_{f} & =\frac{0,075}{\left(\log _{10} R_{n}-2\right)^{2}} \\
R n & =\frac{L w l \cdot V \cdot 1852}{3600 \cdot 1,139 \cdot 10^{-6}}
\end{aligned}
$$

di mana :

viskositas kinematis untuk air tawar $=1,139 \times 10^{-6}$. $\mathrm{S}=\mathrm{L}(\mathrm{Cb} . \mathrm{B}+1,7 \mathrm{~T})$

$\mathrm{RT}=1,429 \mathrm{Rf}$

$\mathrm{Pe}=(\mathrm{RT} . \mathrm{V} .1852) / 1000.3600$

$\mathrm{Pe} \operatorname{mesin}=\eta \mathrm{Pe}$

$\mathrm{PK}=\eta \mathrm{Pe} / 0,7203$

$\eta=1,714$ (efisiensi daya)

Efisiensi daya, mencakup :

Appendage allowance $5 \%$, hull efficiency $=0,75$, transmission loss $=2 \%$, average service conditions $=20 \%$.

\section{HASIL DAN PEMBAHASAN}

\subsection{Hasil Observasi dan Olah Data}

Perahu katamaran berkulit plastik HDPE adalah sebuah perahu yang dibangun di daerah Kebondowo Banyubiru Kab. Semarang. Pembangunan perahu katamaran direncanakan sebagai sarana ekowisata di lokasi wisata Bukit Cinta Rawa Pening Kebondowo Banyubiru. Perahu dibangun dengan menggunakan bahan kombinasi berupa kerangka dari kayu dan kulit lambung berasal dari plastik HDPE bekas drum kemasan. Beberapa bagian dari proses pembuatan dapat dilihat pada Gambar 2.

Data berat kapal diperoleh dengan cara memeriksa jenis kayu dan mengukur konstruksi profil yang digunakan dalam pembuatan perahu, 
kemudian menghitung volume (V) dan mengalikan dengan nilai rapat massanya $\left(\rho, t / \mathrm{m}^{3}\right)$. Hasil perhitungan berat konstruksi dapat dilihat pada Tabel 3 dan 4.

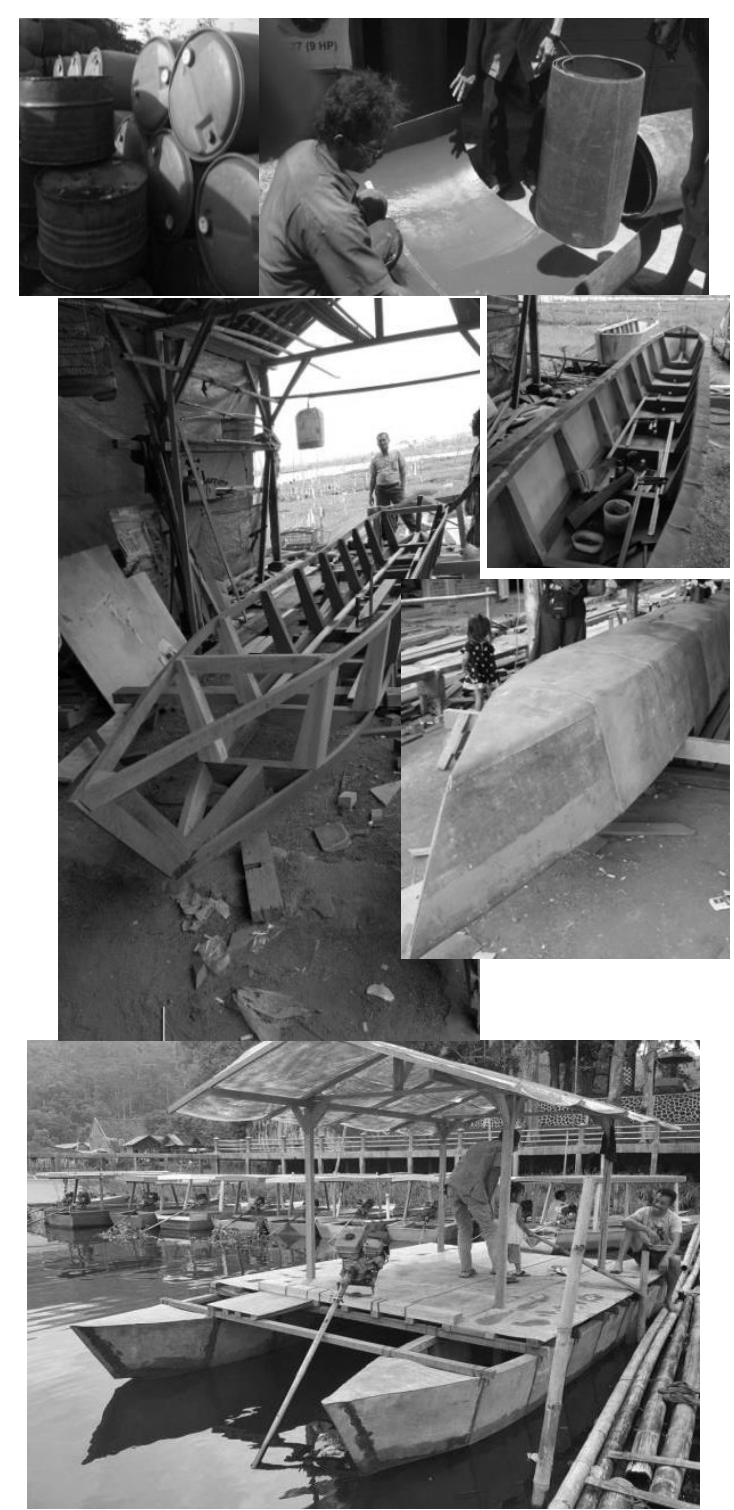

Gambar.2 Proses Pembuatan Perahu Katamaran Berkulit HDPE.

Tabel 3. Perhitungan Berat Konstruksi

\begin{tabular}{llcc}
\hline Bag. Konstuksi & Ukuran & $\boldsymbol{\Sigma}$ & $\begin{array}{l}\text { Berat } \\
\text { (Ton) }\end{array}$ \\
\hline G. Balok & $8 \times 2 \times 660$ & 2 & 0,0192 \\
G. bilga & $7 \times 5 \times 600$ & 2 & 0,0841 \\
Gdg. Sisi & $\begin{array}{l}(7 \times 5 \times 40) \\
\text { x } 9 \text { × } 2\end{array}$ & 18 & 0,0229 \\
Gdg. alas & $\begin{array}{l}10 \times 5,5 \times \\
52\end{array}$ & 7 & 0,0182 \\
Gdg. alas ujung & $10 \times 5,5 \times$ & 2 & 0,0040 \\
$\begin{array}{l}40 \\
\text { L. haluan \& }\end{array}$ & $8 \times 6 \times 54$ & 2 & 0,0047 \\
$\begin{array}{l}\text { Guritan } \\
\text { Jumlah 1 }\end{array}$ & & & 0,0028 \\
lambung & $7 \times 5 \times 44$ & 2 & $\mathbf{0 , 1 5 6 0}$ \\
\hline
\end{tabular}

\begin{tabular}{llll}
\hline $\begin{array}{l}\text { Jumlah 2 } \\
\text { lambung }\end{array}$ & & & $\mathbf{0 , 3 1 2}$ \\
$\begin{array}{l}\text { Pbjr. geladak } \\
\text { B. geladak }\end{array}$ & $6 \times 4 \times 360$ & 11 & 0,0475 \\
Jumlah & $6 \times 4 \times 300$ & 11 & 0,0396 \\
Konstruksi atap & $8 \times 6 \times 160$ & 4 & $\mathbf{0 , 3 9 9 1}$ \\
& $6 \times 4 \times 360$ & 3 & 0,0154 \\
& $6 \times 4 \times 260$ & 2 & 0,0130 \\
& $5 \times 3 \times 260$ & 8 & 0,0156 \\
& & & $\mathbf{0 , 0 5 0 2}$ \\
Berat Total & & & $\mathbf{0 , 4 4 9}$ \\
\hline
\end{tabular}

Keterangan :

$\Sigma=$ jumlah konstruksi yang digunakan.

Tabel 3 menjelaskan tentang jumlah kerangka kayu yang dibutuhkan untuk pembangunan perahu berkulit plastik HDPE. Berat konstruksi diperoleh dengan cara mengalikan setiap voleme $\left(\mathrm{m}^{3}\right)$ dari setiap profil konstruksi dengan berat jenis dari kayunya. Beberapa bagian konstruksi menggunakan jenis kayu yang sama, misal ; galar balok, galar bilga, kayu untuk konstruksi atap menggunakan kayu Suren, sedangkan gading-gading, linggi haluan dan buritan menggunakan kayu Bangkirai.

Jenis kayu yang berdensitas tinggi pada umumnya memiliki kekuatan yang lebih baik dari kayu berdensitas rendah. Densitas atau berat jenis kering udara kayu Suren $(U=15 \pm 3 \%)$, min 0,38 ton $/ \mathrm{m}^{3}$ dan max 0,5 ton $/ \mathrm{m}^{3}$. Berat jenis kering udara kayu Bangkirai, min 0,6 ton $/ \mathrm{m}^{3}$ dan max 1,16 ton $/ \mathrm{m}^{3}$ dengan nilai rata-rata $0,91 \mathrm{ton} / \mathrm{m}^{3}$. [10]

Kebutuhan material kerangka kayu untuk pembuatan perahu katamaran dengan bahan 100 $\%$ terbuat dari kayu (berkulit lambung dari kayu), sebagian besar memiliki ukuran dan jumlah yang sama dengan kebutuhan kerangka kayu untuk perahu katamaran berkulit plastik HDPE, sebagaimana ditunjukkan pada Tabel 3. Perbedaan khusus terletak pada sistem penguatan tertentu karena perbedaan penggunaan jenis material. Perbedaan tersebut dapat dilihat pada Tabel 4.

Tabel 4. Perhitungan Berat Konstruksi

\begin{tabular}{lccc}
\hline Bag. Konstuksi & Ukuran & $\boldsymbol{\Sigma}$ & $\begin{array}{c}\text { Berat } \\
\text { (Ton) }\end{array}$ \\
\hline Pbjr. Geladak & $6 \times 4 \times 360$ & 6 & 0,0259 \\
B. geladak & $10 \times 6 \times$ & 6 & 0,0540 \\
& 300 & & \\
Lunas & $12 \times 6$ & 2 & 0,0865 \\
Jumlah & & & $\mathbf{0 , 1 6 6 4}$ \\
Total berat ${ }^{1)}$ & & & $\mathbf{0 , 5 2 8 5}$ \\
\hline
\end{tabular}

Keterangan :

1) Total berat merupakan jumlah berat konstruksi setelah ditambahkan dengan 
berat profil konstruksi yang sama dengan yang termuat pada Tabel 3 .

Balok geladak, pembujur geladak (baik yang tertera pada Tabel 3 maupun Tabel 4 menggunakan jenis kayu Bangkirai, demikian pula profil lunas pada Tabel 4. Selain berat kerangka konstruksi, berat lain yang diperhitungkan dalam berat kapal atau perahu kosong adalah berat dari kulit lambung. Berat dari displesemen kapal adalah penjumlahan dari berat kapal kosong (LWT) ditambah beban seluruh muatan atau bobot mati (DWT). Tabel 5. menunjukkan berat displasemen dari perahu katamaran yang diperbandingkan.

Tabel 5. Perhitungan Displasemen Berat Perahu

\begin{tabular}{lcc}
\hline Bagian Konstruksi & \multicolumn{2}{c}{ Jenis Perahu } \\
& $\begin{array}{c}\text { Plastik HDPE } \\
\text { (ton) }\end{array}$ & $\begin{array}{l}\text { Kayu } \\
\text { (ton) }\end{array}$ \\
\hline Kerangka Lambung & 0,536 & 0,608 \\
Kulit Geladak & 0,084 & 0,151 \\
Kulit Sisi & 0,146 & 0,263 \\
Penumpang & 0,6 & 0,6 \\
(max = 8 orang) & & \\
Jumlah & $\mathbf{1 , 3 6 6}$ & $\mathbf{1 , 6 2 2}$ \\
Toleransi (10 \%) & 0,128 & 0,154 \\
Berat Displasemen & $\mathbf{1 , 5 0 3}$ & $\mathbf{1 , 7 8 4}$ \\
\hline
\end{tabular}

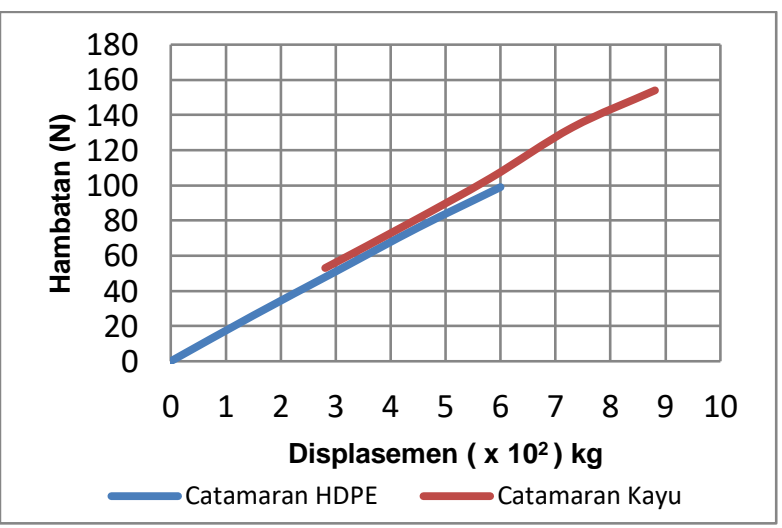

Gambar 3. Hubungan displasemen dengan hambatan.

Analisa pengaruh perbedaan berat akibat penggunaan material alternatif sebagaimana diuraikan di atas, dapat dilakukan dengan menggunakan beberapa rumus empiris. Pada perhitungan hambatan kapal, rumus empiris yang dimaksud tercantum dalam Persamaan 10 dan Persamaan 11. dan ketentuan yang berlaku secara umum tentang komposisi faktor penyusun nilai hambatan Total Kapal, dalam hal nilai tahanan gesek dapat berkisar $60-70 \%$ dari hambatan total kapal. Ditetapkan dalam perhitungan ini nilai hambatan gesek adalah $70 \%$ dari hambatan total kapal. Hasil analisis hubungan antara perubahan displasemen terhadap hambatan dapat dilihat pada Gambar 3.

Dalam ukuran L, B, H, dan k/L yang sama, perbedaan jumlah berat kulit lambung antara material plastik HDPE dengan kayu menghasilkan perbedaan nilai hambatan yang timbul karena adanya perubahan berat displasemen. Pada sarat muatan kosong untuk perahu katamaran HDPE maka telah terjadi penambahan berat sebesar 256 $\mathrm{kg}$ (setara dengan tambahan muatan penumpang 4 orang dengan berat rata $65 \mathrm{~kg}$ ). Kelebihan berat tersebut identik dengan penambahan jumlah kapasitas muat dari perahu. Hal ini akan memberikan keuntungan secara ekonomis.

Selain keuntungan penambahan kapasitas, secara teknis berkurangnya berat displasemen perahu katamaran HDPE akan menyebabkan turunnya nilai hambatan dari kapal. Pengaruh perubahan berat displasemen terhadap hambatan perahu tersebut dapat dilihat pada Gambar 3. Nilai displasemen kapal katamaran HDPE lebih kecil dari pada displasemen kapal katamaran kayu. Berat displasemen yang lebih kecil akan memberikan nilai sarat kapal yang lebih kecil, untuk ukuran Lwl, B, H yang sama. Hal ini akan menyebabkan berkurangnya luas permukaan basah (WSA) dari perahu atau kapal. Luas permukaan ini akan berpengaruh pada nilai hambatan gesek perahu. Hambatan gesek ini memiliki porsi terbesar dalam nilai hambatan total perahu, yang mana nilainya dapat berkisar antara $60-70 \%$ dari nilai hambatan total perahu.

Hasil perhitungan displasemen untuk kedua jenis kapal katamaran menunjukkan perbedaan nilai displasemen $\Delta_{\Delta}=1784-1503 \mathrm{~kg}$, yaitu 281 $\mathrm{kg}$ lebih ringan untuk kapal katamaran HDPE. Sedangkan perbedaan LWT dari kapal katamaran secara khusus antara kapal berkulit plastik HDPE dengan material kayu mencapai $256 \mathrm{~kg}$ atau $25 \%$ dari total berat konstruksi kapal berkulit kayu.

Perubahan displasemen tersebut di atas memberikan tambahan nilai hambatan sebesar $\mathbf{R}_{\Delta}$ $=560-510 \mathrm{~N}$ atau sebesar $50 \mathrm{~N}(8,8 \%)$. Perubahan nilai hambatan ini akan berkorelasi dengan jumlah konsumsi bahan bakar dari mesin yang digunakan. Dengan demikian keputusan untuk menarik manfaat dari efisiensi penggunaan material plastik HDPE dapat dilakukan dengan mempertahankan nilai sarat yang sama dengan sarat perahu kapal kayu dan terjadi penambahan kapasitas muat dari perahu atau kapal katamaran HDPE menjadi \pm 12 orang. Cara lain untuk menarik manfaat efisiensi sebagaimana dimaksud adalah mempertahankan kapasitas muat seperti kapasitas muat perahu kayu ( 8 orang penumpang) dengan nilai sarat berubah lebih kecil. Perubahan nilai sarat yang lebih kecil akan berpengaruh pada 
pengurangan nilai hambatan dan akan memberikan penghematan bahan bakar.

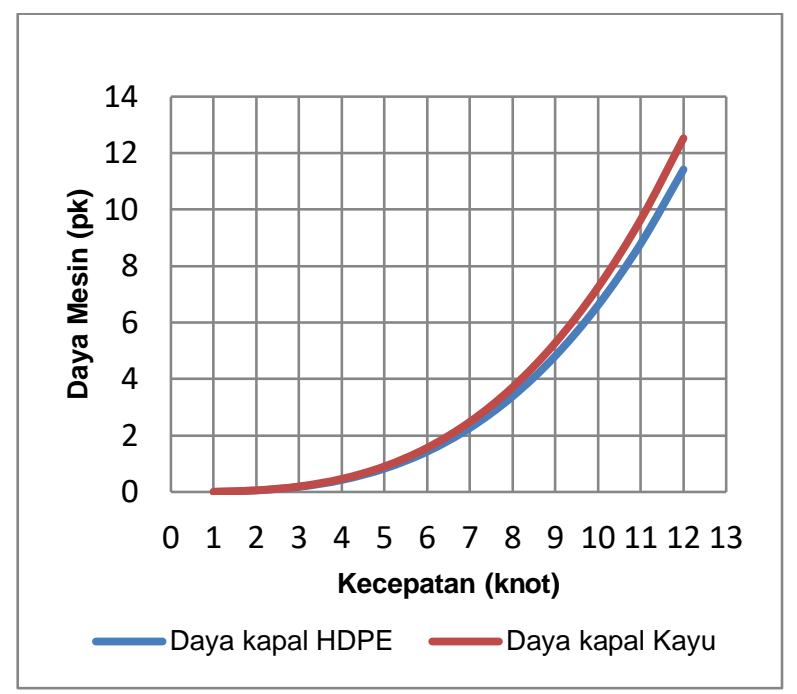

Gambar 4. Hubungan hambatan dan kebutuhan daya mesin.

Gambar 4, menjelaskan bahwa perubahan kecepatan akan berpengaruh pada kebutuhan daya dari mesin penggerak. Semakin cepat kapal bergerak maka daya PK yang diperlukan juga semakin besar. Hal ini disebabkan antara lain karena faktor hambatan kapal saat bergerak di air. Ketika kapal Katamaran berkulit plastik HDPE diproyeksikan pada kecepatan 9 knot maka dibutuhkan daya sebesar 4,8 PK, sedangkan untuk kapal katamaran kayu untuk kecepatan yang sama dibutuhkan daya sebesar 5,3 PK. Perbedaan kebutuhan daya pada kecepatan 9 knot tersebut akan berpengaruh pada konsumsi bahan bakar. Berdasarkan mesin penggerak yang disediakan di lapangan yaitu mesin berdaya 6,5 PK, maka pengunaan mesin yang dimaksud telah mencukupi kebutuhan daya dari kedua jenis kapal tersebut. Langkah penghematan untuk kapal katamaran HDPE dapat dilakukan dengan mengganti spesifikasi mesin dengan daya yang lebih rendah, yaitu mesin penggerak berdaya $5 \mathrm{PK}$.

Selain faktor berat yang berpengaruh terhadap nilai hambatan dan kapasitas muat, perlu pula dilakukan pemeriksaan terhadap karakteristik desain dari perahu katamaran. Berdasarkan data hasil observasi dapat ditetapkan kriteria desain yang akan diperbandingkan dengan mengacu pada kriteria desain katamaran [9], dengan hasil dapat dilihat pada Tabel 6 .

Tabel 6. menjelaskan tentang kriteria yang diperoleh dari hasil observasi dan analisis data, maka dapat diketahui bahwa hampir semua kriteria untuk desain katamaran baik yang berkulit plastik HDPE maupun berkulit kayu, telah memenuhi syarat kriteria desain, kecuali nilai block coefficient $(\mathrm{Cb})$. Nilai $\mathrm{Cb}$ untuk perahu katamaran yang dibangun oleh pengrajin perahu tradisional relatif cukup besar bila dibandingkan dengan kriteria acuan.

Tabel 6. Karakteristik Katamaran

\begin{tabular}{lcc}
\hline Ukuran dan Kriteria & K. HDPE & K. Kayu \\
\hline Loa & 6,6 & 6,6 \\
Lwl & 6,3 & 6,35 \\
T & 0,26 & 0,31 \\
Lw1/B1 & 9,23 & 9,85 \\
B1/D & 1,3 & 1,3 \\
s/L & 0,37 & 0,37 \\
S/B1 & 3,6 & 3,6 \\
B1/T & 2,5 & 2,1 \\
Cb & 0,7 & 0,7 \\
\hline
\end{tabular}

\section{KESIMPULAN}

Hasil penelitian ini menjelaskan bahwa penggunaan bahan alternatif plastik HDPE bekas drum kemasan dapat memberikan manfaat efisiensi pada penggunaan bahan bakar, dengan indikator kebutuhan daya mesin yang relatif kecil untuk kecepatan maksimum 9 Knot.

Daya mesin pada kecepatan tersebut dapat dipenuhi dengan menurunkan spesifikasi mesin dengan kapasitas daya 5 PK dari 6,5 PK daya mesin yang digunakan sebelumnya. Cara lain untuk meningkatkan keuntungan adalah mempertahankan sarat (d) dari katamaran berkulit plastik HDPE sama dengan sarat (d) untuk katamaran berkulit kayu, maka akan diperoleh kelebihan kapasitas penumpang $\pm 50 \%$, yaitu dari 8 orang penumpang menjadi 12 orang.

Berdasarkan kriteria desain perahu katamaran dapat diketahui bahwa kedua jenis kapal yang diobservasi telah memenuhi hampir semua kriteria, kecuali nilai block coefficient $(\mathrm{Cb})$ yang relatif cukup besar.

\section{DAFTAR PUSTAKA}

[1] O. M. Faltinsen, Hydrodynamics of HighSpeed Marine Vehicle, Cambridge: Cambridge University Press, 2005.

[2] U.S. Departement of Commerce Maritime Administration, 1969, Catamaran Study, GENERAL DYNAMICS Quincy Division

[3] Mujiarto Iman, 2005, Sifat Karakteristik Material Plastik Dan Bahan Aditif, Traksi. Vol. 3. No. 2.

[4] Feldman Dorel, Hartomo Anton, J., 1995, Bahan Polimer Konstruksi Bangunan, PT Gramedia Pustaka Utama, Jakarta.

[5] Amiruddin Wilma, Sasmito Hadi Eko, Kiryanto, 2014, Pemanfaatan Material Plastik HDPE Bekas drum Kemasan 
sebagai Kulit Lambung Perahu, KAPAL, Vol. 11, No. 3 hal $162-169$.

[6] D. Setyawan, I K. A. P. Utama, Murdijanto, 2010, A. Sugiarso1, and A. Jamaluddin, Development of Catamaran Fishing Vessel, IPTEK, The Journal for Technology and Science, Vol. 21, No. 4, hal. $167-173$

[7] Tupper Eric, 2002, Introduction to Naval Architecture, Butterworth Heinemann OXFORD

[8] Molland, A.F., Wilson, P.A., Taunton, D.J., 2003, Resistance experiments on a systematic series of high speed displacement monohull and catamaran forms in shallow water, Ship Science Report No. 127 University of Southampton.

[9] Stevens Robert, M., 1972, New Dimensions for Naval Catamaran, Naval Ship Research and Development Center, Bethesda Maryland.

[10] Insel, M. and Molland, A.F., 1992, An Investigation into Resistance Components of High-Speed Displacement Catamarans, Trans. of Royal Institute of Naval Architects, Vol.134, pp 1-20

[11] BKI, 1996, Buku Peraturan Klasifikasi dan Konstruksi Kapal Laut (Peraturan Kapal Kayu), Biro Klasifikasi Indonesia, Jakarta. 